\title{
Effect of Incorporating Different Amounts of Chia to Develop a Nutritious Kulfi
}

\author{
Syeda Shaista Fathima ${ }^{1}$, Shruti Kabra ${ }^{2}$ \\ ${ }^{1}$ Post Graduate Student, Food and Nutrition Department, OUCW, Hyderabad, India \\ ${ }^{2}$ Assistant Professor, Food and Nutrition Department, OUCW, Hyderabad, India
}

\begin{abstract}
Kulfi is a popular frozen Indian dessert which is made of dairy products consumed by all age groups. The present study was an effort in the direction of producing a nutritious kulfi suitable for all age groups. To enhance the nutritive value of kulfi chia seeds were added, thus raising its fibre,calcium, iron and omega-3 fatty acid content. Kulfi is made with $1.2 \%, 3 \%, 4.5 \%, 6 \%, 7.5 \%, 9 \%$ of chia seed flour. The nutritive values were calculated where energy and protein content does not change much but the fibre and iron content raised with the increase in the chia flour content of the product. The fibre content of basic, var-1, var-2, var-3, var-4, var-5 \& var-6 is $0.1 \mathrm{mg}, 0.7 \mathrm{mg}, 1.3 \mathrm{mg}, 2 \mathrm{mg}, 3 \mathrm{mg}$, 3mg, $4 \mathrm{mg}$ and iron content is $1 \mathrm{mg}, 1.02 \mathrm{mg}, 1.05 \mathrm{mg}, 1.68 \mathrm{mg}, 2 \mathrm{mg}, 2.68 \mathrm{mg}$, 3mg respectively Basic and six variations were standardized and subjected to sensory analysis. The result was statistically analyzed. Kulfi made with $6 \%$ chia seed flour was more accepted than others based on all organoleptic properties. The selected variation was subjected for nutrient analysis (fibre\&protein). Replacement of chia flour to custard improved protein content to 1.81gms more than basic and fibre content 3.68gms more than basic. Hence this study suggest that effect of incorporating different amounts of chia seed powder develops a nutritious kulfi.
\end{abstract}

Keywords: Chia seeds, Kulfi

\section{Introduction}

Salvia hispanica, commonly known as chia, is a species of flowering plant in the mint family, Lamiaceae, native to central and southern Mexico and Guatemala

Chia is grown commercially for its seed, a food that is rich in omega-3 fatty acids, since the seeds yield 25-30\% extractable oil, including $\alpha$-linolenic acid (ALA). Of total fat, the composition of the oil can be 55\% $\omega-3,18 \% \omega-6,6 \% \omega-$ 9 , and $10 \%$ saturated fat.

Chia seeds are typically small ovals with a diameter of about $1 \mathrm{~mm}$ (0.039 in). They are mottle-colored with brown, gray, black and white. The seeds are hydrophilic, absorbing up to 12 times their weight in liquid when soaked. While soaking, the seeds develop a mucilaginous gel-like coating that gives chia-based beverages a distinctive texture.

Nutrient content and food uses:

According to the USDA, a one ounce (28 gram) serving of chia seeds contains 9 grams of fat, 5 milligrams of sodium, 11 grams of dietary fiber, 4 grams of protein, $18 \%$ of the recommended daily intake of calcium, $27 \%$ phosphorus and $30 \%$ manganese. These nutrient values are similar to other edible seeds, such as flax or sesame. Chia contains beneficial long-chain triglycerides (LCT) in the right proportion to reduce cholesterol on arterial walls. Chia is a rich source of calcium it contains a vital mineral called boron, which acts as catalyst for the absorption and utilization of calcium by the body.

\section{Health benefits}

Cholesterol levels: reductions of upto $25 \%$ have been noted within 8 to 10 weeks of starting Chia.

Heart disease: People who eat an ALA (alpha Linolenic acid) diet are less likely to suffer a fatal heart attack.
Type 2 diabetes: Chia seeds form a physical barrier between carbohydrates and digestive enzymes slowing the conversion of carbohydrates into sugar thus reducing blood sugar levels and diminishing sugar peaks and troughs.

Digestive disorders: Chia has been reported as bringing relief to digestive disorders such as Crohn's disease and Irritable Bowel Syndrome (IBS). Chia seeds are high in fibre and will regulate your system to where it should be.

Rich in protein and dietary fiber, chia seeds support healthy weight management by helping you feel less hungry and more satisfied throughout the day Chia seeds include B vitamins, vitamins $\mathrm{C}$ and $\mathrm{E}$, as well as minerals, such as calcium, magnesium, boron and iron - important nutrients that contribute to overall health, strength and vitality.

Brain health: Chia helps improve concentration (due to high omega 3 and 6 content) it has provided relief from depression and children with ADHD and Autism have shown some improvement.

Hormone levels: Chia will help balance hormone levels and reduce the symptoms associated with PMT, painful periods and menopause. The chia seed has great potential to be used in the food industry. In this regard, studies have shown that in aqueous media, this seed is wrapped in a copious polysaccharide slime producing a gel. The latter is excellent for digestion and with the grain itself is a nutritious food.

\section{Materials and Method}

Kulfi is a popular frozen dairy product it is often described as Indian subcontinent ice cream. kulfi is similar to ice cream but it is not whipped, resulting in solid dense frozen product. It is easy to prepare at home and it appeals to all 


\section{International Journal of Science and Research (IJSR) \\ ISSN (Online): 2319-7064}

Index Copernicus Value (2015): 78.96 | Impact Factor (2015): 6.391

age groups, so kulfi was prepared using chia seed to improve nutrient content of the product.

\section{Product Development}

The product has been developed as a snack items, which is well suited for all age group. The main ingredient is chia seed which is known as store house of nutrients. One standing point of recipe is easy and quick method of preparation. The result of product developed consists of a snack item for the household use.

Frozen dairy products like ice cream, kulfi etc appeals all the age groups.So kulfi was developed using chia seeds in the variation. Thus providing concentrated source of energy, protein, fat(omega-3 fatty acid), calcium and fibre.

\section{Procurement of Sample}

The seed used in the formulation of chia kulfi and the other ingredients was procured from the local market .Milk and malai from dairy farm. The seeds are grounded to fine powder and used.

\section{Formulation}

Six formulations of chia kulfies $(\mathrm{K} 1, \mathrm{~K} 2, \mathrm{~K} 3, \mathrm{~K} 4, \mathrm{~K} 5, \mathrm{~K} 6)$ were developed using chia seed flour to partially substitute custard powder (corn starch) in different levels. The ingredients of kulfi were accurately weighed and mixed to yield a uniform mixture for each formulation. The chia seed flour was added in six doses of $1 \%, 2 \%, 3 \%, 4 \%, 5 \% \& 6 \%$ i.e. (K1, K2, K3, K4, K5, K6) respectively.

\section{Standardisation}

The standardization is the process where a recipe is tested a number of times and found a satisfactory in quantity and yield. It is a gradual trial and error process. To develop kulfi which is high in protein, calcium, omega-3 fatty acid and fibre content. Custard powder which is used in basic receipe is replaced by adding known quantity of chia seed flour, the variations are made and the quantities are decided by making repeated trials of the preparations. The amount were finalized by assessing the appearance, texture, taste of the variations.

Table 1: Composition of Chia Kulfi

\begin{tabular}{|c|c|c|c|c|c|c|c|}
\hline Ingredients & $\begin{array}{c}\text { Basic } \\
(g)\end{array}$ & $\begin{array}{c}\text { VAR-1 } \\
(g)\end{array}$ & $\begin{array}{c}\text { VAR-2 } \\
(g)\end{array}$ & $\begin{array}{c}\text { VAR-3 } \\
(g)\end{array}$ & $\begin{array}{c}\text { VAR-4 } \\
(g)\end{array}$ & $\begin{array}{c}\text { VAR-5 } \\
(g)\end{array}$ & $\begin{array}{c}\text { VAR-6 } \\
(g)\end{array}$ \\
\hline $\begin{array}{c}\text { Chia seed } \\
\text { powder }\end{array}$ & - & 1.5 & 3.0 & 4.5 & 6.0 & 7.5 & 9.0 \\
\hline $\begin{array}{c}\text { Custard } \\
\text { powder }\end{array}$ & 9.0 & 7.5 & 6.0 & 4.5 & 3.0 & 1.5 & -- \\
\hline Whole milk & 120 & 120 & 120 & 120 & 120 & 120 & 120 \\
\hline $\begin{array}{c}\text { Whole milk } \\
\text { powder }\end{array}$ & 5 & 5 & 5 & 5 & 5 & 5 & 5 \\
\hline Malai/khoa & 5 & 5 & 5 & 5 & 5 & 5 & 5 \\
\hline Sugar & 10 & 10 & 10 & 10 & 10 & 10 & 10 \\
\hline Saffron sticks & $2-3$ & $2-3$ & $2-3$ & $2-3$ & $2-3$ & $2-3$ & $2-3$ \\
\hline Pistachio & $2-3$ & $2-3$ & $2-3$ & $2-3$ & $2-3$ & $2-3$ & $2-3$ \\
\hline
\end{tabular}

\section{Sensory Evaluation}

The sensory evaluation was carried out on the basic and variations of kulfi after it gets frozen. A group of 25 nontrained panelistsi.e; students were participated in the sensory analysis. The taste panels were conducted in a calm place .The time selected for conducting sensory evaluation for both basic and the variations was 11:am when the panel members are neither too hungry nor well fed. The panelists made hedonic evaluation of the samples. The panelists were asked to assess the kulfi for over all acceptability based on the colour, taste, and the texture.

\section{Nutrient Analysis}

The developed product was then subjected for two major nutrient analyses. The chemical analysis was done to estimate the amount of protein and fibre content in the product using kjeldhal method and AOAC international methods respectively.

\section{Result and Discussion}

Kulfi was prepared using chia seed flour to enhance the nutritive value of the product. Six variations were prepared using different amount of chia seed flour.All the formulated recipes were standardized first and then submitted for palatability and acceptability trials. The mean score of appearance, colour and texture of basic kulfi was little high compared to the kulfi with variations of chia seed flour. whereas the taste of the kulfi with variations was much more accepted than the basic kulfi, chia added taste to the kulfi.If the food is palatable it is acceptable the mean score of acceptability of kulfi [basic] was less than the kulfi with variations. The most accepted variation of the kulfi was selected and was sent for nutrient analysis. The protein content of kulfi [basic] is $4 \mathrm{~g}$ and that of selected variation is $5.81 \mathrm{~g}$, fibre content of kulfi [basic] is $0.11 \mathrm{~g}$ and that of selected variation is $3.79 \mathrm{~g}$.

\section{Conclusion}

Kulfi is a popular frozen Indian dessert which is made of dairy products and sugar and filled with nutty goodness and flavoured with cardamom or saffron. This is a rich dessert and perfect for summer times and parties. It is widely consumed in all parts of the country. So this study was an effort in the direction of producing a nutritious kulfi suitable for all age groups. Chia seeds were added to kulfi, thus raising its fibre, calcium, iron and omega-3 fatty acid content. The smooth texture and the consistency of kulfi is due to custard powder which is also a good binding agent is replaced with chia seed powder, which upgraded the nutritious quality of the kulfi especially the fibre and omega3 fatty acid content which is usually not found in any other kulfies. Chia seed flour was included in the variations as the nutrient quality of chia is superior to custard powder.All the variations were formulated and standardized by conducting repeated trails. Chia kulfi was prepared with different proportions of chia seed powder.Panel of 20 judges evaluated the palatability and acceptability of the product. The palatability of basic and variations were accepted in terms of appearance, taste, flavor etc. Statistical analysis of palatability trails has shown that $t$ value at $p<0.005$ was found to be significant for all i.e basic and variations. The nutritive value of basic and variations were calculated.The basic recipe provides $289 \mathrm{~K}$.cal while var-1, var-2, var-3, var-4, var-5 \& var-6 provided $288 \mathrm{~K}$.cal, 288K.cal, 288K.cal, $287 \mathrm{~K}$.cal, $287 \mathrm{~K}$.cal, $287 \mathrm{~K}$.cal respectively. The decrease in the energy content in the variations was due to incorporation of the chia and decreased in the content of the custard 


\section{International Journal of Science and Research (IJSR) \\ ISSN (Online): 2319-7064}

Index Copernicus Value (2015): 78.96 | Impact Factor (2015): 6.391

powder. The basic recipe provided $8 \mathrm{gm}$ of protein while variation was $8 \mathrm{gm}, 9 \mathrm{gm}, 9.2 \mathrm{gm}, 9.4 \mathrm{gm}, 10.2 \mathrm{gm} \& 11 \mathrm{gm}$ respectively. And the fibre content was $0.10 \mathrm{mg}$ for basic and $0.7 \mathrm{mg}, 1.3 \mathrm{mg}, 2 \mathrm{mg}, 2.8 \mathrm{mg}, 3 \mathrm{mg} \& 4 \mathrm{mg}$ for variations. Iron content of basic is $1.0 \mathrm{mg}$ and $1.02 \mathrm{mg}, 1.05 \mathrm{mg}, 1.68 \mathrm{mg}$, $2 \mathrm{mg}, 2.68 \mathrm{mg} \& 3 \mathrm{mg}$ for variations. The fibre, iron and protein has increased due to the addition of chia flour in the variations.

Chia seeds are also a very good source of omega 3 fatty acid and calcium.further studies can be done to estimate omega 3 fatty acid content and calcium content and its bioavailability.

\section{References}

[1] Ayerza, R. (1995). Oil content and fatty-acid composition of chia (Salvia-Hispanica) from 5 northwestern locations in Argentina. Journal of the American Oil Chemists Society, 72(9), 1079-1081.

[2] Ayerza, R., \& Coates, W. (2005). Ground chia seed and chia oil effects on plasma lipids and fatty acids in the rat. Nutrition Research, 25(11), 995-1003.

[3] Reyes-Caudillo, E., Tecante, A., \& Valdivia-Lopez, M. A. (2008). Dietary fibre content and antioxidant activity of phenolic compounds present in Mexican chia (Salvia hispanica L.) seeds. Food Chemistry, 107(2), 656-663. Journal of Food Research Vol. 1, No. 4; 201295

[4] Muñoz L. A., Aguilera J.M., Rodriguez-Turienzo L., Cobos A., Diaz O., Characterization and microstructure of films made from mucilage of Salvia hispanica and whey protein concentrate, Journal of Food Engineering, 111(3): 511-518

[5] Muñoz, L. A., A. Cobos, Diaz, O., Aguilera, J. M., (2012). Chia seeds: Microstructure, mucilage extraction and hydration. Journal of Food Engineering 108(1): 216-224.

[6] Ayerza, R. (1995). "Oil content and fatty acid composition of chia (Salvia hispanica L.) from five northwestern locations in Argentina " Journal of the American Oil Chemists' Society 72(9): 1079-1081.

[7] Ayerza, R. (1996). Fatty acid composition, protein and oil content of chia (Salvia hispanica L.) grown in Perú, Columbia and Agentina. Third European Symposium on Industrial Crops and Products Reims, France, Elsevier: 9.

[8] Ayerza, R. and W. Coates (2001b). Chia seeds: new source of omega-3 fatty acids, natural antioxidants, and dietetic fiber. Tucson, Arizona, USA, Southwest Centerfor Natural Products Research \& Commercialization, Office of Arid Lands Studies.

[9] Ayerza, R. and W. Coates (2005b). "Ground chia seed and chia oil effects on plasma lipids and fatty acids in the rat." Nutrition Research 25(11): 995-1003.

[10] Benichou, A., A. Aserin and N. Garti (2002). "Proteinpolysaccharide interactions for stabilization of food emulsions." Journal of Dispersion Science and Technology 23(1): 93 - 12

[11]L.Turgeon (2007). "Improved gelling properties of whey protein isolate by addition of xanthan gum." Food Hydrocolloids 21(2): 159-166.

[12] Bushway, A. A., P. R. Belyea and B. R. J. (1981). "Chia seed as a source of oil, polysaccharide, and protein." Journal of Food Science 46(5): 1349-1350
[13] Reyes-Caudillo, Tecante A, Valdivia-Lopez MA. 2008. Dietary fiber content and antioxidant activity of phenolic compounds present in Mexican chia (Salvia hispanica L.) seeds. Food Chem 107: 656-663.

[14] J. L. Bresson, A. Flynn, M. Heinonen, et al., "Opinion on the safety of "Chia seeds (Salvia hispanica L.) and ground whole Chia seeds" as a food ingredient," The European Food Safety Authority Journal, vol. 996, pp. 1-26, 2009.

[15] V. Y. Ixtaina, S. M. Nolasco, and M. C. Tomás, "Physical properties of chia (Salvia hispanica L.) seeds,'Industrial Crops and Products, vol. 28, no. 3, pp. 286-293, 2008

[16]F. Jin, D. C. Nieman, W. Sha, et al., "Supplementation of milled chia seeds increases plasma ALA and EPA in postmenopausal women" Plant Foods For Human Nutrition, vol. 67, pp. 105-110, 2010V. Vuksan, A. L. Jenkins, A. G. Dias et al., "Reduction in postprandial glucose excursion and prolongation of satiety: possible explanation of the long-term effects of whole grain Salba (Salvia hispanica L.)," European Journal of Clinical Nutrition, vol. 64, no. 4, pp. 436-438, 2010

[17] Fernandez, S. M. Vidueiros, R. Ayerza, W. Coates, and A. Pallaro, "Impact of chia (Salvia hispanica L.) on the immune system: preliminary study," Proceedings of the Nutrition Society, vol. 67, article E12, 2000

[18] R. Ayerza and W. Coates, "Omega-3 enriched eggs: the influence of dietary $\alpha$-linolenic fatty acid source on egg production and composition," Canadian Journal of Animal Science, vol. 81, no. 3, pp. 355-362, 2000. 